\title{
EFFECT OF FIRM AGAR ON THE SWARMING OF PROTEUS AND CLOSTRIDIUM SPECIES AND ON THE COLONIES OF CLINICALLY IMPORTANT BACTERIA
}

\author{
Nancy J. Hayward, G. M. Incledon and Jennifer E. SpragG \\ Department of Microbiology, Monash University Medical School, \\ Prahran, 3181, Australia
}

\section{Plates IX-XI}

THE use of firm agar (FA) to inhibit the swarming of Proteus and Clostridium spp. was first reported by Hayward and Miles (1943). A description of its preparation and use followed (Hayward, 1945, 1947). Some medical bacteriologists have favoured FA to prevent the swarming of Proteus spp. (Stokes, 1960; Crowley, Bradley and Darrell, 1969), but more recently its value has been questioned because it sometimes failed to prevent swarming (Stokes, 1975) and reduced the growth of certain clostridia (Williams, 1971; Willis and Williams, 1972).

The ideal anti-swarming medium should be suitable for all swarming bacteria, non-inhibitory to the growth of any bacterium to be isolated from mixtures that include swarmers, and easy to prepare. No medium satisfies all of these criteria. The chief disadvantages of FA are the experience and special attention required for its preparation, and the unfamilar appearance it gives to colonies of common bacteria (Crowley et al., 1969; Smith, 1972).

The present work was undertaken to provide a detailed description of the preparation of FA media, an assessment of the effectiveness of FA in preventing the swarming of proteus colonies, information on the effect of FA on surface viable counts of clinically important bacteria, and an account of the colonial morphology on FA of a variety of bacteria likely to be isolated in clinical laboratories.

\section{MATERIALS AND METHODS \\ Organisms}

Proteus mirabilis and Proteus vulgaris cultures (167 and 14 respectively), all of which swarmed on " routine " nutrient agar (see below), were used to test the inhibition of swarming by FA. Of the $P$. mirabilis cultures, 164 were freshly isolated; they came from faeces (87), urine (56), respiratory tract (7), wounds (6), genital tract (4), ear (1), eye (1), water (1) and sewage (1). The remaining three were from culture collections, namely, the National Collection of Type Cultures, London (strain NCTC9559), the Monash University Culture Collection and the Queensland University Culture Collection. Of the $P$. vulgaris cultures, nine were freshly isolated; they came from faeces (6), urine (2) and the nose (1). The remaining five were from culture collections, namely, the National Collection of Type Cultures, London (strain NCTC4636), the Monash University Culture Collection, the

Received 6 Sept. 1977; accepted 12 Oct. 1977.

J, MED. MICROBIOL.-VOL. 11 (1978) 
Queensland University Culture Collection (two strains) and the collection of the Institute of Medical and Veterinary Science, Adelaide.

Swarming cultures of Clostridium tetani and Clostridium septicum were obtained as isolates from wounds.

The organisms used for experiments on viable counts and colonial morphology were from culture collections, except for the culture of Neisseria gonorrhoeae which was freshly isolated.

The identities of all cultures were confirmed by the methods of Cowan and Steel (1974).

\section{Media}

The term "routine" is used to describe media containing $1.2 \%$ agar.

The preparation of FA media required attention to detail. Care was needed to ensure that the period of steaming was sufficient to dissolve the agar completely. Boiling-over during autoclaving was prevented by the use of flasks that were large in proportion to the amount of medium, e.g., a 500-ml flask was used for $100 \mathrm{ml}$ of medium and a $750-\mathrm{ml}$ flask for $200 \mathrm{ml}$ of medium; it was also necessary to reduce the autoclave pressure slowly after sterilisation. When heat-labile ingredients were to be added, the sterile FA solution took longer than routine agar solutions to cool to $50^{\circ} \mathrm{C}$, e.g., $30 \mathrm{~min}$. for $200 \mathrm{ml}$ of medium, and uniform mixing was more difficult in FA than in routine agar. Plates containing heat-labile ingredients were poured at $50^{\circ} \mathrm{C}$, tipping each dish to spread the agar as quickly as possible because FA rapidly became very viscous on further cooling. Volumes of up to $250 \mathrm{ml}$ were easier to handle than larger volumes because comparatively little cooling of the main bulk took place during the time taken to pour the plates.

Oxoid Agar No. 3, Oxoid Agar No. 4 and Davis New Zealand Agar were used in routine media and all three performed similarly when used in FA to inhibit swarming. Oxoid Agar No. 3 was used in all media for bacterial colony counts of aerobic species. Oxoid Agar No. 4 was used for counts of anaerobes.

Nutrient agar was prepared from $2.5 \%(\mathrm{w} / \mathrm{v})$ Oxoid Nutrient Broth No. 2, containing yeast extract powder $0.3 \%(\mathrm{w} / \mathrm{v})$ and four concentrations of agar, namely, $2 \cdot 8,3 \cdot 2,3.6$ and $4 \%(\mathrm{w} / \mathrm{v})$, at $p \mathrm{H} 7 \cdot 2$.

Single-layer routine blood agar was prepared to give final concentrations of Oxoid Nutrient Broth No. 2, $2.5 \%(w / v)$, yeast extract powder $0.3 \%(w / v)$, agar $1.2 \%(w / v)$, at $p \mathrm{H} 7 \cdot 2$, and horse blood $10 \%(\mathrm{w} / \mathrm{v})$.

Double-layer routine blood agar consisted of a lower layer containing $\mathrm{NaCl} 0.85 \%(\mathrm{w} / \mathrm{v})$, Oxoid Bacteriological Peptone $0.5 \%$ and agar $1.2 \%(\mathrm{w} / \mathrm{v})$, at $p \mathrm{H} 5.8$, and an upper layer of the same composition as single-layer routine blood agar.

Single-layer firm blood agar was prepared to give final concentrations of Oxoid Nutrient Broth No. 2, $2.5 \%(\mathrm{w} / \mathrm{v})$, yeast extract powder $0.3 \%(\mathrm{w} / \mathrm{v})$, eight concentrations of agar, namely, $1 \cdot 5,1 \cdot 8,2 \cdot 1,2 \cdot 4,2 \cdot 7,3,3 \cdot 3$ and $3 \cdot 6 \%(\mathrm{w} / \mathrm{v})$, at $p \mathrm{H} 7 \cdot 2$, and horse blood $10 \%(\mathrm{v} / \mathrm{v})$. The broth, yeast extract and agar were mixed with water without swirling the agar up the sides of the flask, dissolved by steaming at $100^{\circ} \mathrm{C}$ and autoclaved at $121^{\circ} \mathrm{C}$ for $15 \mathrm{~min}$. The agar solution was cooled to $50^{\circ} \mathrm{C}$. Haemolysis was avoided by the use of fresh blood and by holding it at $50^{\circ} \mathrm{C}$ for as short a time as possible. The flask of agar solution was held in the waterbath while the blood was added by running it down the inside wall of the flask and mixed slowly and thoroughly by rotation, with care to avoid the formation of bubbles. The medium was poured immediately. Plates were tilted on their lids to dry the medium at $37^{\circ} \mathrm{C}$ for $20 \mathrm{~min}$., or longer if free water was apparent on the surface. Further drying of FA was unnecessary.

Double-layer firm blood agar contained a lower layer that consisted of $\mathrm{NaCl} 0.85 \%(\mathrm{w} / \mathrm{v})$, Oxoid Bacteriological Peptone 0.5\% (w/v) and either 1.2, 2.4, 3.6, 4.2 or $4.5 \%(\mathrm{w} / \mathrm{v})$ agar at $p \mathrm{H} \mathrm{5.8.} \mathrm{This} \mathrm{medium} \mathrm{was} \mathrm{autoclaved} \mathrm{at} 121^{\circ} \mathrm{C}$ for $15 \mathrm{~min}$., cooled at $50^{\circ} \mathrm{C}$ for $10 \mathrm{~min}$., then poured and allowed to set with the Petri-dish lids tilted open. The plates containing the lower layers were tilted on their lids to dry at $37^{\circ} \mathrm{C}$ until no free moisture was visible; this required about 60,40 and $25 \mathrm{~min}$. respectively for plates containing $1.2 \%, 2.4 \%$ and $3 \cdot 6-$ $4.5 \%$ concentrations of agar. The upper layer contained up to $4.5 \%$ agar and, unless 
otherwise stated, $10 \%$ horse blood; it was prepared, poured and dried as for single-layer firm blood agar.

Routine and firm heated-blood agars contained Oxoid Nutrient Broth No. 2, $2.5 \%(\mathrm{w} / \mathrm{v})$, yeast extract powder $0.3 \%(\mathrm{w} / \mathrm{v})$, either 1.2 or $3.6 \%$ agar $(\mathrm{w} / \mathrm{v})$, at $p \mathrm{H} 7 \cdot 2$, and $10 \%(\mathrm{v} / \mathrm{v})$ horse blood. The nutrient agar solutions were prepared as for single-layer blood agars and cooled to $75^{\circ} \mathrm{C}$. Blood was added to the agar solutions and held for about $5 \mathrm{~min}$. at $75^{\circ} \mathrm{C}$ until it was chocolate-brown. Plates were poured immediately. The lids were tilted open for 5 to $10 \mathrm{~min}$. at room temperature while the agar was setting. The medium was dried at $37^{\circ} \mathrm{C}$ for $30 \mathrm{~min}$.

Firm gelatin agar consisted of $2.5 \%$ Oxoid Nutrient Broth No. 2 containing gelatin $0.4 \%(\mathrm{w} / \mathrm{v})$ and agar $3.6 \%(\mathrm{w} / \mathrm{v})$ at $p \mathrm{H} 7.2$. It was sterilised at $115^{\circ} \mathrm{C}$ for $10 \mathrm{~min}$; plates were then poured immediately, allowed to set, and dried at $37^{\circ} \mathrm{C}$ for $40 \mathrm{~min}$.

\section{Viable counts}

The method of Miles, Misra and Irwin (1938) was used and the colony counts recorded were the mean number that grew from six drops, two on each of three plates.

\section{Incubation}

All cultures were incubated at $37^{\circ} \mathrm{C}$. Anaerobic cultures were incubated in a jar equipped with a "cold" catalyst of palladiumised-alumina pellets and, unless otherwise stated, evacuated to a negative pressure of $600-650 \mathrm{~mm}$ of mercury before admitting hydrogen. Cultures to be incubated in air with an increased tension of carbon dioxide were placed in a jar containing $10 \%$ carbon dioxide.

\section{RESULTS}

Agar concentration in single-layer media necessary to prevent swarming of Proteus spp. in air

A trial of four concentrations of agar in nutrient agar showed that $3.2 \%$ and higher concentrations controlled swarming of three strains each of $P$. mirabilis and $P$. vulgaris. A further trial of nine concentrations of agar ranging from 1.2 to $3.6 \%$ in single-layer blood agar showed that $3 \%$ and higher concentrations controlled the swarming of a strain of $P$. vulgaris. A concentration of $3.6 \%$ agar, three times the concentration of agar in routine media, was chosen for firm media.

Firm and routine media that were initially at room temperature and that were free from surface moisture were tilted on their lids at $37^{\circ} \mathrm{C}$ for trials of periods of drying of up to $1 \mathrm{~h}$. Drying for $1 \mathrm{~h}$ did not prevent the swarming of $P$. mirabilis on routine blood agar. Drying for up to $20 \mathrm{~min}$. progressively reduced the size of colonies of $P$. mirabilis on firm blood agar but more prolonged drying did not have any further effect.

After incubation for 2 days on firm blood agar, colonies of $P$. mirabilis and $P$. vulgaris varied considerably in size; they tended to be larger than after 1 day but never swarmed over the medium (figs. 1 and 2).

When firm blood agar was used to isolate 173 strains of $P$. mirabilis or $P$. vulgaris from natural sources the swarming of all of them was controlled. All 173 isolates covered the entire surface of routine blood agar during overnight incubation. 
Agar concentrations in each layer of double-layer blood agar necessary to prevent swarming of Proteus spp. in air and anaerobically

Agar concentrations from 1.2 to $4.5 \%$ in the lower layer and of 3.6 or $4.5 \%$ in the upper layer were tested.

The swarming of a strain of $P$. mirabilis on medium with an upper layer containing $3.6 \%$ agar was not controlled in air when the lower layer contained $1.2 \%$ agar but was controlled when the lower layer contained 2.4 or $3.6 \%$ agar. It was concluded that media containing 3.6\% agar in both layers would be advisable for cultures to be incubated in air.

Colonies of $P$. mirabilis in anaerobic jars evacuated to a negative pressure of $300 \mathrm{~mm}$ of mercury during the establishment of anaerobiosis were very small after 1 day but tended to become thin and effuse on further incubation. Even $3.6 \%$ agar in both layers did not prevent a tendency for outgrowths to develop after incubation for 2 days. Trials of higher concentrations showed that $4.5 \%$ agar in both layers was optimal for controlling the size of colonies of $P$. mirabilis when anaerobic incubation was to be longer than overnight. It seemed possible that the humidity in the anaerobic jar, resulting from the palladiumcatalysed formation of water from hydrogen and oxygen, might be responsible for the greater tendency of proteus colonies to swarm anaerobically. When air amounting to a pressure of $600-650 \mathrm{~mm}$ of mercury was removed from jars during the establishment of anaerobiosis, leaving less oxygen to form water, the tendency of colonies of $P$. mirabilis to produce outgrowths was reduced. Under these circumstances, a $3.6 \%$ concentration of agar in both layers of firm medium (figs. 3 and 4 ) was equivalent to $4.5 \%$ under circumstances in which the anaerobic jar was subjected to a negative pressure of only $300 \mathrm{~mm}$ of mercury. Evacuation to a negative pressure of $600-650 \mathrm{~mm}$ of mercury was chosen for all tests on clostridia.

On double-layer firm blood agar both layers of which contained either 3.6 or $4.5 \%$ agar, strains of $C$. tetani and $C$. septicum that swarmed over the entire surface of routine blood agar produced discrete colonies (figs. 5 to 8).

\section{Optimal conditions of incubation of double-layer firm blood agar to show haemolysis of streptococci}

Both layers contained $3.6 \%$ agar and cultures were incubated both in air and anaerobically. The haemolysis produced by Streptococcus pyogenes, Streptococcus pneumoniae and Streptococcus mitior was more clearly demonstrated by medium containing $10 \%$ horse blood than by that containing $7 \%$. The higher concentration of blood was used in all routine and firm blood-agar media.

Colonies of Str. pyogenes were very small and did not show clear $\beta$-haemolysis in air but each discrete colony was $\beta$-haemolytic after anaerobic incubation for $18 \mathrm{~h}$. Where colonies were closely packed a dense brownish precipitate surrounded by an outer rim of $\beta$-haemolysis developed in the medium both in air and anaerobically, particularly after incubation for 2 days.

Colonies of Str. mitior were clearly $\alpha$-haemolytic after incubation in air for 
$18 \mathrm{~h}$. Where colonies were closely packed a dense olive-green precipitate with an outer rim of $\alpha$-haemolysis developed in the medium, particularly after incubation for 2 days.

Colonies of Str. pneumoniae were $\alpha$-haemolytic after incubation in air for $19 \mathrm{~h}$; $\alpha$-haemolysis was particularly clear in areas where colonies were closely packed and no dense precipitate developed in the medium.

Colonies of Streptococcus faecalis showed clear $\beta$-haemolysis after incubation for $21 \mathrm{~h}$ both in air and anaerobically. No dense precipitate developed in the medium where colonies were closely packed.

It was concluded that double-layer firm blood agar in which both layers contained $3.6 \%$ agar could be used for the isolation of streptococci in the presence of $P$. mirabilis or $P$. vulgaris. Haemolysis would be particularly clear if Str. pyogenes were incubated anaerobically and if Str. mitior and Str. pneumoniae were incubated in air. Either aerobic or anaerobic incubation would be suitable for Str. faecalis.

\section{Surface viable counts on routine and $F A$ media}

Several species of bacteria that might be found mixed with swarming strains of Proteus spp. in clinical specimens were tested in parallel on routine and firm blood agar (table). The agar concentration in all firm media was $3.6 \%$, except that clostridia were counted on media containing both $3.6 \%$ and $4.5 \%$ agar. The $3.6 \%$ agar was shown to prevent the swarming of a strain of P. mirabilis.

The table shows no evidence that FA inhibited the growth of any species tested. However when Clostridium chauvoei was tested on two other occasions, counts on FA were only one-third to one-half those on routine agar.

\section{Colonial morphology of a number of bacterial species on routine and $F A$ media}

The appearances on FA as compared with those on routine agar media were as follows.

Escherichia coli colonies (figs. 9 and 10) were more domed, with an effuse margin, irregular edge, rougher and duller surface and denser texture. Salmonella kauffmannii var. typhimurium colonies (figs. 11 and 12) had an irregular edge, roughened surface, effuse periphery, and more clearly demarcated centre. Shigella sonnei colonies (figs. 13 and 14) were more raised, with an irregular edge and duller surface. Klebsiella aerogenes colonies (figs. 15 and 16) had a slightly crenated edge, duller surface, and denser texture. Pseudomonas aeruginosa colonies (figs. 17 and 18) were more domed with a duller surface. Staphylococcus aureus colonies (figs. 19 and 20) were more domed and slightly roughened, with a less shiny surface and denser texture. Staphylococcus epidermidis colonies (figs. 21 and 22) were more domed with a duller surface and denser texture. Str. pneumoniae colonies (figs. 23 to 26 ) were more domed and more opaque, with a less shiny surface. Str. pyogenes colonies (figs. 27 and 28) were more domed, with a less shiny surface and denser texture. Str. mitior colonies (figs. 29 and 30) were more domed, with a less shiny surface. 
TABLE

Surface viable counts and sizes of colonies on routine $(1.2 \%)$ and firm $(3.6$ or $4.5 \%)$ agar media

\begin{tabular}{|c|c|c|c|c|c|c|}
\hline \multirow{2}{*}{ Organism } & \multirow{2}{*}{$\begin{array}{l}\text { Type of blood- } \\
\text { agar culture } \\
\text { medium and } \\
\text { atmosphere }\end{array}$} & \multirow{2}{*}{$\begin{array}{c}\text { Duration } \\
\text { of } \\
\text { incubation } \\
\text { (h) }\end{array}$} & \multicolumn{2}{|c|}{$\begin{array}{l}\text { Surface } \\
\text { viable count } \\
\text { on }\end{array}$} & \multicolumn{2}{|c|}{$\begin{array}{c}\text { Colony } \\
\text { diameter }(\mathrm{mm}) \\
\text { on }\end{array}$} \\
\hline & & & $\begin{array}{c}\text { routine } \\
\text { agar }\end{array}$ & $\begin{array}{l}\text { firm } \\
\text { agar* }\end{array}$ & $\begin{array}{c}\text { routine } \\
\text { agar }\end{array}$ & $\underset{\text { agar* }}{\text { firm }}$ \\
\hline Proteus mirabilis & $\begin{array}{l}\text { Double-layer } \\
\text { Air }\end{array}$ & $\begin{array}{l}24 \\
48 \\
24 \\
48\end{array}$ & $\begin{array}{l}\ldots \\
\cdots \\
\cdots\end{array}$ & $\begin{array}{l}\cdots \\
\cdots \\
\cdots\end{array}$ & $\begin{array}{c}\text { Swarming } \\
\ldots \\
\ldots \\
\ldots\end{array}$ & $\begin{array}{l}1 \cdot 8 \\
3 \cdot 3 \\
1 \cdot 8 \dagger \\
3 \cdot 5 \dagger\end{array}$ \\
\hline Escherichia coli & $\begin{array}{l}\text { Single-layer } \\
\text { Air }\end{array}$ & 20 & $\dddot{40}$ & 38 & $2 \cdot 4$ & $2 \cdot 1$ \\
\hline $\begin{array}{l}\text { Salmonella kauffmannii } \\
\text { var. typhimurium }\end{array}$ & $\begin{array}{l}\text { Single-layer } \\
\text { Air }\end{array}$ & 20 & 28 & 25 & $2 \cdot 1$ & 2.6 \\
\hline Shigella sonnei & $\begin{array}{l}\text { Double-layer } \\
\text { Air }\end{array}$ & 17 & 49 & 43 & $2 \cdot 2$ & $1 \cdot 8$ \\
\hline Klebsiella aerogenes & $\begin{array}{l}\text { Single-layer } \\
\text { Air }\end{array}$ & 22 & 10 & 9 & $2 \cdot 2$ & $2 \cdot 2$ \\
\hline Pseudomonas aeruginosa & $\begin{array}{l}\text { Single-layer } \\
\text { Air }\end{array}$ & 22 & 68 & 65 & 1.0 & $0 \cdot 8$ \\
\hline Staphylococcus aureus & $\begin{array}{l}\text { Single-layer } \\
\text { Air }\end{array}$ & 18 & 53 & 45 & 1.0 & $0 \cdot 7$ \\
\hline $\begin{array}{l}\text { Staphylococcus } \\
\text { epidermidis }\end{array}$ & $\begin{array}{l}\text { Single-layer } \\
\text { Air }\end{array}$ & 18 & 32 & 29 & $1 \cdot 1$ & 0.8 \\
\hline Streptococcus pneumoniae & $\begin{array}{l}\text { Double-layer } \\
\text { Air }\end{array}$ & $\begin{array}{l}21 \\
41\end{array}$ & 14 & 16 & $\begin{array}{l}1 \cdot 9 \\
2 \cdot 4\end{array}$ & $\begin{array}{l}0.8 \\
1.2\end{array}$ \\
\hline Streptococcus pyogenes & $\begin{array}{l}\text { Double-layer } \\
\text { Anaerobic }\end{array}$ & $\begin{array}{l}41 \\
21 \\
38\end{array}$ & $\dddot{86}$ & $\dddot{87}$ & $\begin{array}{l}0.5 \\
1.0\end{array}$ & $\begin{array}{l}1 \cdot 2 \\
0.3 \\
0.6\end{array}$ \\
\hline Streptococcus mitior & $\begin{array}{l}\text { Double-layer } \\
\text { Air }\end{array}$ & $\begin{array}{l}21 \\
38\end{array}$ & $\dddot{99}$ & $11 i$ & $\begin{array}{l}0.4 \\
1.0\end{array}$ & $\begin{array}{l}0.4 \\
0.7\end{array}$ \\
\hline Streptococcus faecalis & $\begin{array}{l}\text { Double-layer } \\
\text { Air }\end{array}$ & $\begin{array}{l}21 \\
42\end{array}$ & $\dddot{68}$ & $\dddot{69}$ & $\begin{array}{l}1 \cdot 6 \\
2 \cdot 2\end{array}$ & $\begin{array}{l}1.5 \\
1.7\end{array}$ \\
\hline Haemophilus influenzae & $\begin{array}{l}\text { Heated } \\
\text { Air }\end{array}$ & $\begin{array}{l}21 \\
42\end{array}$ & $\begin{array}{l}10 \ddot{8} \\
105\end{array}$ & $\begin{array}{l}1106 \\
122\end{array}$ & $\begin{array}{l}1.0 \\
1.5\end{array}$ & $\begin{array}{l}0.9 \\
1.3\end{array}$ \\
\hline Neisseria gonorrhoeae & $\begin{array}{l}\text { Heated } \\
\text { Air }+\mathrm{CO}_{2}\end{array}$ & $\begin{array}{l}25 \\
47\end{array}$ & $\begin{array}{l}19 \\
19\end{array}$ & $\begin{array}{l}26 \\
32\end{array}$ & $\begin{array}{l}0.4 \\
1.0\end{array}$ & $\begin{array}{l}0.2 \\
0.5\end{array}$ \\
\hline Proteus mirabilis & $\begin{array}{l}\text { Double-layer } \\
\text { Anaerobic }\end{array}$ & $\begin{array}{l}20 \\
42 \\
20 \\
42\end{array}$ & $\begin{array}{l}\cdots \\
\cdots \\
\ldots\end{array}$ & $\begin{array}{l}\ldots \\
\ldots \\
\ldots\end{array}$ & $\begin{array}{c}\text { Swarming } \\
\ldots \\
\ldots \\
\ldots\end{array}$ & $\begin{array}{l}0.5 \\
1 \cdot 3 \\
0 \cdot 5 \dagger \\
1 \cdot 1 \dagger\end{array}$ \\
\hline Clostridium tetani & $\begin{array}{l}\text { Double-layer } \\
\text { Anaerobic }\end{array}$ & $\begin{array}{l}20 \\
42 \\
20 \\
42\end{array}$ & $\begin{array}{l}\cdots \\
\cdots \\
\cdots\end{array}$ & $\begin{array}{l}\cdots \\
\cdots \\
\cdots\end{array}$ & $\begin{array}{c}\text { Swarming } \\
\ldots \\
\ldots\end{array}$ & $\begin{array}{l}1.7 \\
3 \cdot 2 \\
1.5 \dagger \\
2 \cdot 5 \dagger\end{array}$ \\
\hline Clostridium septicum & $\begin{array}{l}\text { Double-layer } \\
\text { Anaerobic }\end{array}$ & $\begin{array}{l}20 \\
42 \\
20 \\
42\end{array}$ & $\begin{array}{l}\cdots \\
\cdots \\
\cdots\end{array}$ & $\begin{array}{l}\cdots \\
\cdots \\
\cdots\end{array}$ & $\begin{array}{c}\text { Swarming } \\
\ldots \\
\ldots\end{array}$ & $\begin{array}{l}1 \cdot 5 \\
2 \cdot 9 \\
1 \cdot 0 \dagger \\
2 \cdot 1 \dagger\end{array}$ \\
\hline Clostridium welchii & $\begin{array}{l}\text { Double-layer } \\
\text { Anaerobic }\end{array}$ & 22 & $\dddot{14}$ & $\begin{array}{l}\dddot{15} \\
14\end{array}$ & $\dddot{1} \cdot 3$ & $\begin{array}{l}0.8 \\
0.8 \dagger\end{array}$ \\
\hline Clostridium oedematiens & $\begin{array}{l}\text { Double-layer } \\
\text { Anaerobic }\end{array}$ & 20 & 14 & 11 & 0.6 & $\begin{array}{l}0.7 \\
0.8+\end{array}$ \\
\hline Clostridium chauvoei & $\begin{array}{l}\text { Double-layer } \\
\text { Anaerobic }\end{array}$ & 20 & $\begin{array}{l}\dddot{34} \\
\cdots\end{array}$ & $\begin{array}{l}36 \\
40 \dagger\end{array}$ & $\begin{array}{l}\dddot{0.5} \\
\ldots\end{array}$ & $\begin{array}{l}0.4 \\
0.5 \dagger\end{array}$ \\
\hline
\end{tabular}

* Firm agar contained 3.6\% agar unless otherwise stated.

$\dagger$ Medium contained $4.5 \%$ agar. 
FIRM AGAR TO PREVENT SWARMING

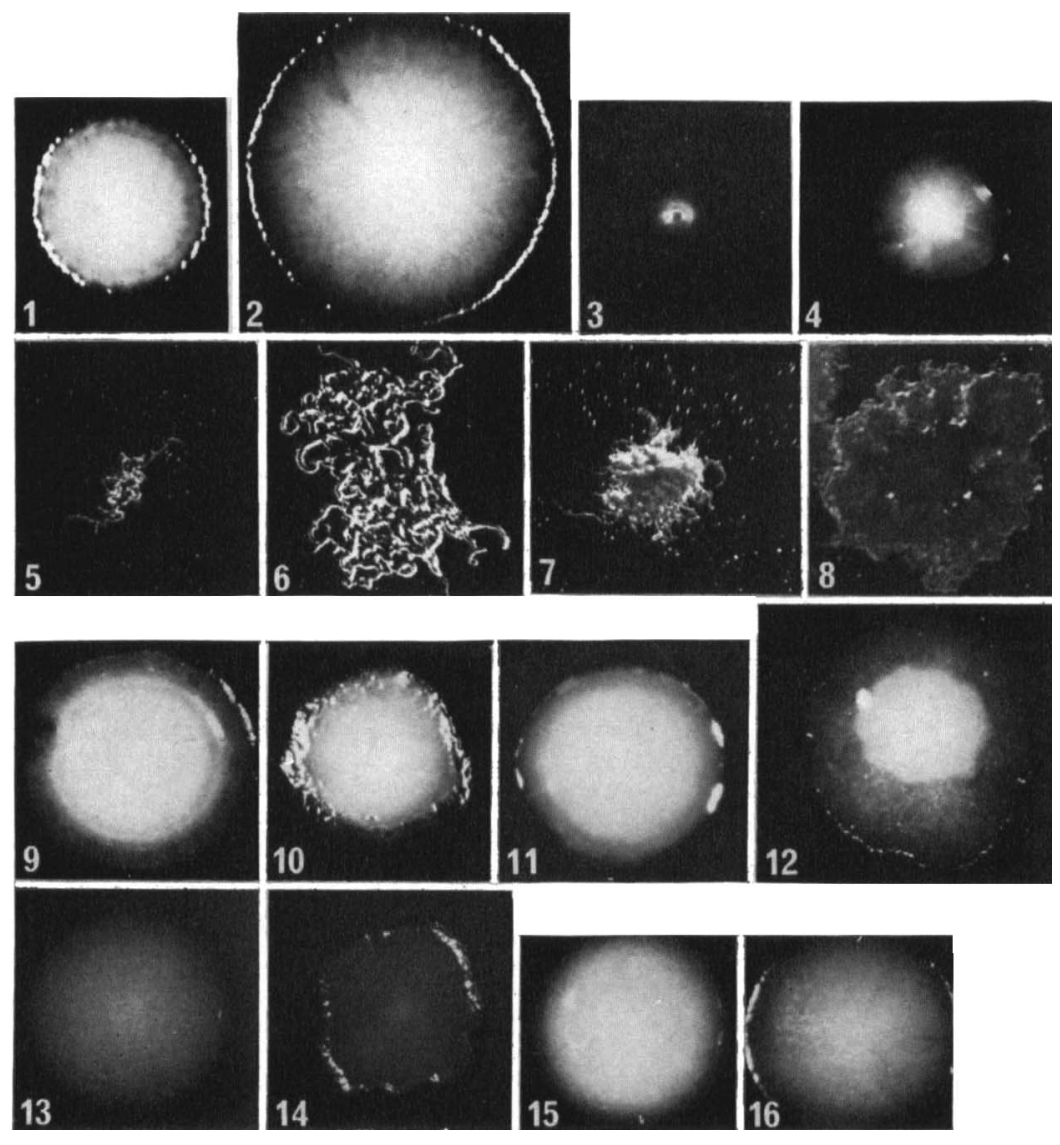

FIGS 1 and 2.-Proteus mirabilis after growth aerobically on double-layer firm blood agar for $20 \mathrm{~h}$ (fig. 1) and $42 \mathrm{~h}$ (fig. 2). $\times 8$.

FIGS 3 and 4.-P. mirabilis after growth anaerobically on double-layer firm blood agar for $20 \mathrm{~h}$ (fig. 3) and $42 \mathrm{~h}$ (fig. 4). $\times 8$.

FIGS 5 and 6.-Clostridium tetani after growth on double-layer firm blood agar for $20 \mathrm{~h} \mathrm{(fig.} \mathrm{5)} \mathrm{and}$ $42 \mathrm{~h}$ (fig. 6). $\times 8$.

Figs 7 and 8.-Clostridium septicum after growth on double-layer firm blood agar for $20 \mathrm{~h}(\mathrm{fig}$. 7) and 42 h (fig. 8). $\times 8$.

FIGS. 9 and 10.-Escherichia coli after aerobic growth for $20 \mathrm{~h}$ on single-layer blood agar containing routine agar (fig. 9) or firm agar (fig. 10). $\times 8$.

FIGS 11 and 12.-Salmonella kauffmannii var. typhimurium after aerobic growth for $20 \mathrm{~h}$ on singlelayer blood agar containing routine agar (fig. 11) or firm agar (fig. 12). $\quad \times 8$.

FIGS 13 and 14.- Shigella sonnei after aerobic growth for $17 \mathrm{~h}$ on double-layer blood agar containing routine agar (fig. 13) or firm agar (fig. 14). $\times 8$.

FIgs 15 and 16.-Klebsiella aerogenes after aerobic growth for $22 \mathrm{~h}$ on single-layer blood agar containing routine agar (fig. 15) or firm agar (fig. 16). $\times 8$. 
FIRM AGAR TO PREVENT SWARMING

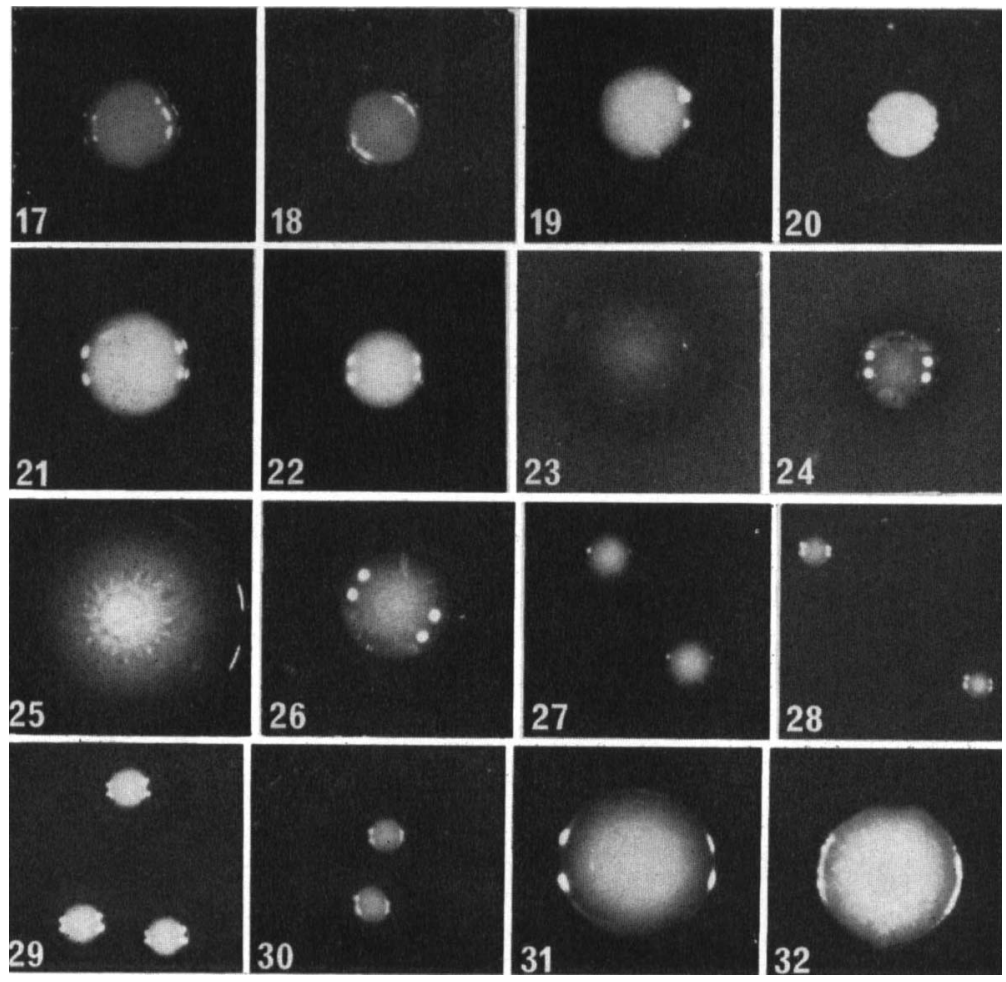

FIGS 17 and 18.-Pseudomonas aeruginosa after aerobic growth for $22 \mathrm{~h}$ on single-layer blood agar containing routine agar (fig. 17) or firm agar (fig. 18). $\times 8$.

FiGs 19 and 20.-Staphylococcus aureus after aerobic growth for $18 \mathrm{~h}$ on single-layer blood agar containing routine agar (fig. 19) or firm agar (fig. 20). $\times 8$.

Figs 21 and 22.-Staphylococcus epidermidis after aerobic growth for $18 \mathrm{~h}$ on single-layer blood agar containing routine agar (fig. 21) or firm agar (fig. 22). $\times 8$.

Figs 23 to 26.-Streptococcus pneumoniae after aerobic growth for $21 \mathrm{~h}$ (fig. 23) and $41 \mathrm{~h}$ (fig. 25) on double-layer blood agar containing routine agar, and for $21 \mathrm{~h}$ (fig. 24) and $41 \mathrm{~h}$ (fig. 26) on double-layer blood agar containing firm agar. $\times 8$.

FIGS 27 and 28.-Streptococcus pyogenes after anaerobic growth for $21 \mathrm{~h}$ on double-layer blood agar containing routine agar (fig. 27) or firm agar (fig. 28). $\times 8$.

Figs 29 and 30.-Streptococcus mitior after aerobic growth for $21 \mathrm{~h}$ on double-layer blood agar containing routine agar (fig. 29) or firm agar (fig. 30). $\times 8$.

Figs 31 and 32.-Streptococcus faecalis after aerobic growth for $21 \mathrm{~h}$ on double-layer blood agar containing routine agar (fig. 31) or firm agar (fig. 32). $\times 8$. 
FIRM AGAR TO PREVENT SWARMING

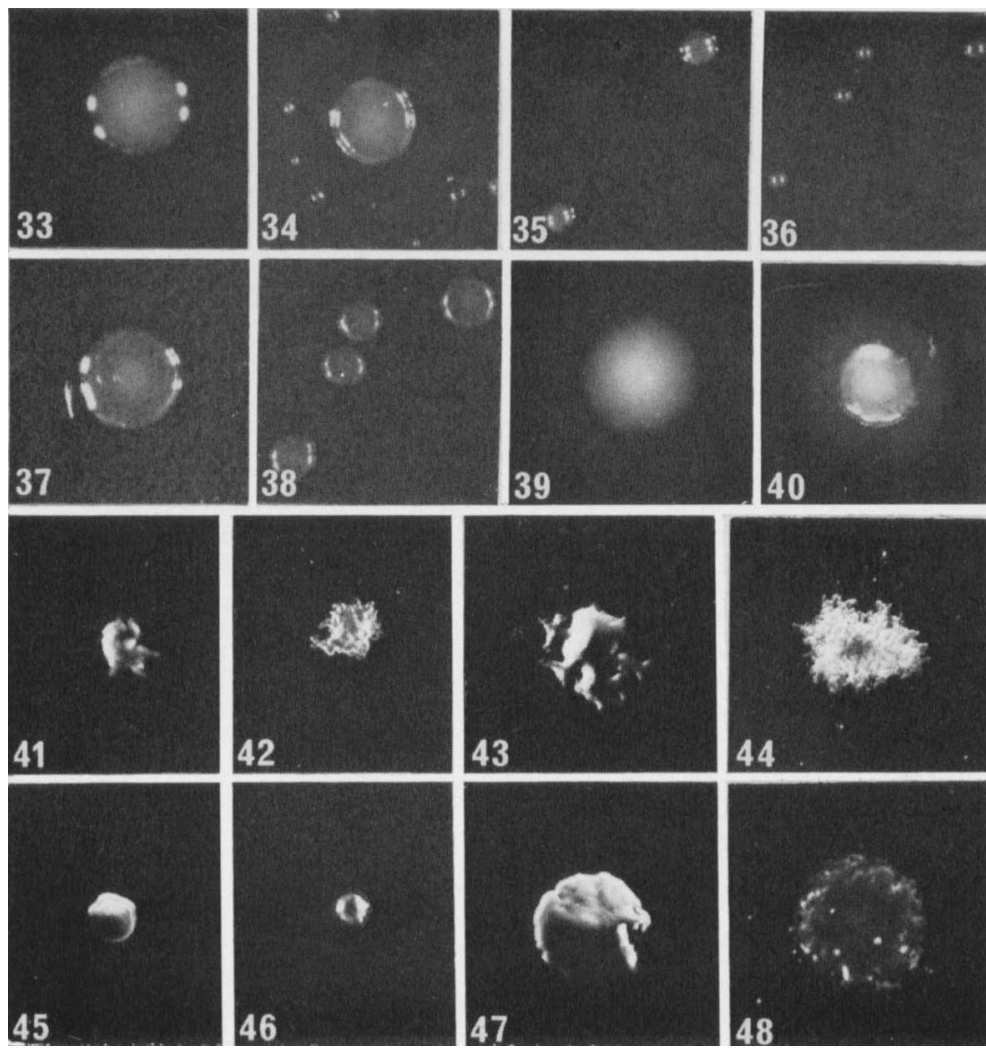

FIGS 33 and 34.-Haemophilus influenzae after aerobic growth for $21 \mathrm{~h}$ on heated blood agar containing routine agar (fig. 33) or firm agar (fig. 34). $\times 8$.

Figs 35 to 38.-Neisseria gonorrhoeae after growth in air plus $\mathrm{CO}_{2}$ for $25 \mathrm{~h}$ (fig. 35) and $47 \mathrm{~h}$ (fig. 37) on heated blood agar containing routine agar, and for $25 \mathrm{~h}$ (fig. 36) and $47 \mathrm{~h}$ (fig. 38) on heated blood agar containing firm agar. $\times 8$.

FIGs 39 and 40.-Clostridium welchii after growth for $19 \mathrm{~h}$ on double-layer blood agar containing routine agar (fig. 39) or firm agar (fig. 40). $\times 8$.

FIGS 41 to 44.-Clostridium oedematiens after growth for $20 \mathrm{~h}$ (fig. 41 ) and $42 \mathrm{~h}$ (fig. 43) on doublelayer blood agar containing routine agar, and for $20 \mathrm{~h}$ (fig. 42) and $42 \mathrm{~h}$ (fig. 44) on double-layer blood agar containing firm agar. $\times 8$.

FIGS 45 to 48.-Clostridium chauvoei after growth for $20 \mathrm{~h}$ (fig. 45) and $42 \mathrm{~h} \mathrm{(fig.} \mathrm{47)} \mathrm{on} \mathrm{double-layer}$ blood agar containing routine agar, and for $20 \mathrm{~h}$ (fig. 46) and $42 \mathrm{~h}$ (fig. 48) on double-layer blood agar containing firm agar. $\times 8$. 
Str. faecalis colonies (figs. 31 and 32 ) had a slightly irregular edge, less shiny surface and greater opacity. Haemophilus influenzae colonies (figs. 33 and 34) were more domed centrally, with a narrow flat margin, irregular edge and duller surface. Neisseria gonorrhoeae colonies (figs. 35 to 38 ) had a slightly irregular edge and a rougher and duller surface. Clostridium welchii colonies (figs. 39 and 40) had a raised centre, a narrow flat margin, and a surface that was rougher, and more opaque. Clostridium oedematiens colonies (figs. 41 to 44) had an edge that was rhizoid instead of arborescent, a less shiny surface and a denser texture. C. chauvoei colonies (figs. 45 to 48 ) had a more irregular edge and a surface that was matt instead of shiny.

\section{General effects of $F A$}

Size. Colonies on FA were smaller than on routine agar (table). For some species the difference was very small, but for others colonies on FA were only half the diameter of those on routine agar. It might therefore be advisable to increase the incubation period for cultures on FA.

Elevation. Colonies on FA were more convex than on routine agar and sometimes had a bevelled or effuse margin.

Edge. Entire edges on routine agar sometimes became undulate or crenate on FA. Arborescent edges became rhizoidal as colonies became compact.

Surface. Colonies on FA were rougher and duller than on routine agar. Smooth colonies showed a beaten-copper or rough appearance and rough colonies became granular. Glistening colonies on routine agar were dull on FA.

Opacity was frequently increased on FA.

\section{Gelatin liquefaction by Proteus spp. on firm gelatin agar}

The swarming of $P$. mirabilis and $P$. vulgaris was inhibited on firm gelatin agar. Two strains each of $P$. mirabilis and $P$. vulgaris showed liquefaction clearly when tested with acid mercuric chloride (Barer, 1946) after 3 days' incubation. One strain each of Proteus rettgeri and Proteus morganii were shown to be negative in the same test.

\section{Discussion}

The swarming of Proteus spp. has attracted an interest that has continued into the present decade without agreement about its mechanism (Brogan, Nettleton and Reid, 1971; Smith, 1972; Bisset, 1973 $a$ and $b$; Fuscoe, 1973; Armitage, Rowbury and Smith, 1974, 1975; Smith, 1975; Bisset and Douglas, 1976). Media that inhibit swarming have also been of practical interest, but no single medium has gained general acceptance. Factors that militate against the ready acceptance of FA include lack of experience of its preparation and the unusual appearances of colonies on it.

No absolute value can be given for the agar concentration that will inhibit swarming. It is necessary to test each agar and, provided that agar from the same source remains in use, the concentration chosen for FA will probably 
continue to be satisfactory. In the present investigation FA containing $3.6 \%$, i.e., three times the concentration used in routine media, was effective. It is of interest that the $6 \%$ agar concentration that Hayward and Miles (1943) used in FA was also, for that particular agar, three times the concentration used in routine media. In testing a new agar it would be advisable to start with three times the routine concentration ("triple-strength agar"). However a somewhat higher concentration may be necessary to control the swarming of Proteus spp. under anaerobic incubation if a negative pressure of only $300 \mathrm{~mm}$ of mercury is generated in the removal of air from the jar during the establishment of anaerobiosis.

The preparation of FA needs attention to detail that is not required for routine agar, but with experience it is not difficult. Another physical method of inhibiting swarming is the use of activated charcoal agar (Smith and Alwen, 1966; Alwen and Smith, 1967). Stokes (1975) recommended medium containing this substance, but nevertheless cited four additional media to inhibit swarming under different circumstances because charcoal agar is difficult to prepare and because charcoal is made ineffective by certain other ingredients of media, notably whole blood.

FA is useful for all bacteria with swarming colonies, including Proteus spp., C. tetani and C. septicum. Special methods are sometimes used for particular purposes. Thus flagellotropic-phage preparations, spread on the surfaces of media, inhibit the swarming of Proteus spp. (Roux and Applebaum, 1972), commercial tetanus antitoxin inhibits the swarming of $C$. tetani (Willis and Williams, 1970; Williams, 1971) and an antiserum to selected strains inhibits the swarming of C. septicum (Willis and Williams, 1972). Williams (1971) and Willis and Williams (1972) found that antiserum-treated media were marginally better than FA for producing discrete colonies of C. tetani and C. septicum. Possibly the agar concentration in their FA (4\%) was not quite high enough and colonies would have been better separated if it had been three times the concentration used in their routine agar (1.5\%). Stokes (1975) found that firm blood agar sometimes failed to inhibit the swarming of Proteus spp. but she did not record the agar concentrations or the incubation conditions, and did not state whether incubation was aerobic or anaerobic. In our experience it has always been possible to obtain discrete colonies of swarmers by the use of a high enough concentration of agar in firm media. Yeast extract promotes swarming (Brogan et al., 1971). The inclusion of yeast extract in media has made our trial of FA even more stringent.

FA has little inhibitory effect on bacteria likely to be found in clinical specimens. In this respect it is superior to antibiotics and chemicals, which continue to be proposed as anti-swarming agents (Williams, 1973a and $b$ ), but which cannot be guaranteed to have no effect on the growth of certain medically-important bacteria. FA has been reported to restrict the free development of colonies of clostridia, particularly C. chauvoei (Williams, 1971; Willis and Williams, 1972). In the present investigation certain observations gave support to this finding, but only in respect of C. chauvoei. C. oedematiens, in addition to other fastidious bacteria such as $N$. gonorrhoeae and $H$. influenzae, 
grew equally well on routine and firm media. However, colonies of many bacteria are smaller on FA than on routine media and it is possible that the falsely low viable counts of clostridia on FA reported in the literature occurred because small colonies were overlooked. Colonies on FA may require longer than those on routine agar to become visible.

The use of FA to prevent swarming has many advantages to compensate for the experience necessary both for its preparation and for the recognition of colonies growing on it. It is often invaluable for specimens that may be expected to contain swarming Proteus spp., such as discharge from abdominal wounds, pus from chronic lesions, rectal swabs to be examined for $N$. gonorroeae, and urine. The descriptions given in this paper should forewarn bacteriologists about differences that may be expected between colonies on FA and those on routine agar.

\section{SUMMARY}

Firm agar media containing 3.6\% agar-three times the concentration of agar in routine media-inhibited the swarming of 167 strains of Proteus mirabilis and 14 strains of Proteus vulgaris incubated in air. The swarming of $P$. mirabilis was also prevented by firm agar when incubation was anaerobic, provided that a negative pressure of $600-650 \mathrm{~mm}$ of mercury was generated in the removal of air from jars before admitting hydrogen for the palladium-catalysed removal of residual traces of oxygen. When a negative pressure of only $300 \mathrm{~mm}$ of mercury was generated there was a tendency for colonies of $P$. mirabilis to develop outgrowths after incubation for 2 days. Firm agar inhibited the swarming of Clostridium tetani and Clostridium septicum.

As judged by a viable-count method, firm agar medium permitted the growth of maximal numbers of colonies for all organisms tested except Clostridium chauvoei; the organisms included Clostridium oedematiens, Haemophilus influenzae, Neisseria gonorrhoeae, Streptococcus pneumoniae and Streptococcus pyogenes.

Precautions necessary for the preparation of firm agar media are defined. Colonies of a number of bacterial species on firm agar are described and illustrated. Firm agar media, being applicable to all bacteria with swarming colonies and practically non-inhibitory to other bacteria, are recommended for the isolation of bacteria from clinical specimens that may contain swarmers.

The care and skill of the photographers, Mrs Lana Zuchowski and Mr Rick Croker, are acknowledged with sincere thanks.

\section{REFERENCES}

Alwen, J. ANd Smith, D. G. 1967. A medium to suppress the swarming of Proteus species. J. appl. Bact., 30, 389.

Armitage, J. P., Rowbury, R. J. And Smith, D. G. 1974. The effects of chloramphenicol, nalidixic acid and penicillin on the growth and division of swarming cells of Proteus mirabilis. J. med. Microbiol., 7, 459.

ARmitage, J. P., RowbURy, R. J. AND Smith, D. G. 1975. Indirect evidence for cell wall and membrane differences between filamentous swarming cells and short non-swarming cells of Proteus mirabilis. J. gen. Microbiol., 89, 199. 
BARER, G. 1946. The rapid detection of gelatin-liquefying organisms. Mon. Bull. Minist. Hlth, $5,28$.

Bisset, K. A. 1973a. The motion of the swarm of Proteus mirabilis. J. med. Microbiol., 6, 33.

Bisset, K. A. $1973 b$. The zonation phenomenon and structure of the swarm colony in Proteus mirabilis. J. med. Microbiol., 6, 429.

Bisset, K. A. AND Douglas, C. W. I. 1976. A continuous study of morphological phase in the swarm of Proteus. J. med. Microbiol., 9, 229.

Brogan, T. D., Nettleton, J. and ReID, C. 1971. The swarming of Proteus on semisynthetic media. J. med. Microbiol., 4, 1.

Cowan, S. T. AND Steel, K. J. 1974. Manual for the identification of medical bacteria, 2nd ed., Cambridge.

Crowley, N., Bradley, J. M. ANd Darrell, J. H. 1969. Practical bacteriology, London, p. 97.

FUSCOE, F. J. 1973. The role of extracellular slime secretion in the swarming of Proteus. Med. Lab. Technol., 30, 373.

Hayward, N. J. 1945. The examination of wounds for clostridia. Proc. Ass. clin. Path., 1, 5.

HAYWARD, N. J. 1947. Laboratory diagnosis of anaerobic infections. In Recent advances in clinical pathology, edited by S. C. Dyke, London, p. 76.

Hayward, N. J. AND Miles, A. A. 1943. Inhibition of Proteus in cultures from wounds. Lancet, $2,116$.

Miles, A. A., MisRa, S. S. AND Irwin, J. O. 1938. The estimation of the bactericidal power of the blood. J. Hyg., Camb., 38, 732.

Roux, S. T. AND Appelbaum, P. C. 1972. A phage-inhibitor for the swarming of Proteus. J. med. Microbiol., 5, 377.

SmIth, D. G. 1972. The Proteus swarming phenomenon. Sci. Prog., Lond., 60, 487.

SmITH, D. G. 1975. Inhibition of swarming in Proteus spp. by tannic acid. J. appl. Bact., 38, 29.

Smith, D. G. AND Alwen, J. 1966. Effect of activated charcoal on the swarming of Proteus. Nature, Lond., 212, 941.

Stokes, E. J. 1960. Clinical bacteriology, 2nd ed., London, p. 113.

Stokes, E. J. 1975. Clinical bacteriology, 4th ed., London, p. 149.

Williams, F. D. 1973a. Abolition of swarming of Proteus by p-nitrophenyl glycerin: general properties. Appl. Microbiol., 25, 745.

Williams, F. D. $1973 b$. Abolition of swarming of Proteus by $p$-nitrophenyl glycerin: application to blood agar media. Appl. Microbiol., 25, 751.

Williams, K. 1971. Some observations on Clostridium tetani. Med. Lab. Technol., 28, 399.

Willis, A. T. AND Williams, K. 1970. Some cultural reactions of Clostridium tetani. J. med. Microbiol., 3, 291.

Willis, A. T. AND Williams, K. 1972. Prevention of swarming of Clostridium septicum. J. med. Microbiol., 5, 493. 